\title{
Morphology of the second zoeal stage of Grapsus adscensionis (Osbeck, 1765) (Crustacea, Decapoda, Grapsoidea) confirms larval characters of the family Grapsidae
}

JOSÉ MARÍA LANDEIRA ${ }^{1,3}$ \& JOSÉ A. CUESTA ${ }^{2}$

${ }^{I}$ Departamento de Biología Animal, Facultad de Biología, Universidad de La Laguna, Campus Anchieta, 38206 La Laguna, Spain (e-mail: jm_landeira@yahoo.es).

${ }^{2}$ Instituto de Ciencias Marinas de Andalucía, CSIC. Avenida República Saharaui, 2, 11519 Puerto Real, Cádiz, Spain (e-mail: jose.cuesta@icman.csic.es).

${ }^{3}$ Corresponding author

Key words: Grapsidae, larval development, Grapsus adscensionis, zoea, megalopa Running Head: Morphology of the zoea II of Grapsus adscensionis

\begin{abstract}
The morphology of the second zoeal stage of Grapsus adscensionis, hatched from ovigerous specimens collected in the supralittoral zone of Taliarte Harbour, Gran Canaria (Canary Islands, NE Atlantic), is described and illustrated in detail for the first time. The comparison of its larval morphology with those of other species of Grapsidae provides information for the characterization of the zoeal morphology of grapsids, with implications in the phylogenetic relationships within the family, as well as an aid in identification of plankton samples.
\end{abstract}

\section{Introduction}

The Grapsidae MacLeay, 1838, presently is a small family consisting of 40 species in 8 genera ( $\mathrm{Ng}$ et al. 2008). Despite of being mainly intertidal, and therefore ovigerous females are easy to collect, the complete larval development of few of these species is 
known. This is due to the small size of the first zoeal stage that are difficult to feed (see Ingle 1987), and the long duration of the zoeal phase that often fails in laboratory cultures (see Cuesta et al. 2011). The exception to these problems is Metopograpsus H. Milne Edwards, 1853, which also present peculiarities in larval morphology and in the number of zoeal stages. Such peculiarities are reflected in a recent molecular phylogeny where Metopograpsus is placed in a basal position, clearly differentiated from the rest of the grapsid genera (Schubart 2011).

All present known larval data for the family Grapsidae are summarized by Cuesta et al. (2011: table 2). Larval descriptions are known for seven out of the eight valid genera, but the complete larval development is known for only four species (one for Geograpsus Stimpson, 1858, three for Metopograpsus). The rest of larval stages described correspond mainly to zoeae I (for 18 species) and a few later stages for 6 species. Despite the fact that larval morphology of grapsids is far from being completely known, Cuesta et al. $(1997,2006)$ and Cuesta \& Schubart (1999) proposed a set of characters that allows defining the morphology of the larval stages of Grapsidae (with the exception of Leptograpsodes Montgomery, 1931, because there are no larval data known). This set of features was emended by Cuesta et al. (2011) with new features for later zoeal stages that require some modification of the patterns in mouthpart setations.

There are few larval data on Grapsus Lamarck, 1801, and these are mainly restricted to the zoea I, as in Grapsus adscensionis (Cuesta et al. 1997), G. fourmanoiri Crosnier, 1965, (Flores et al. 2003), G. grapsus (Linnaeus, 1758) (Guerao et al. 2001) and G. tenuicrustatus (Herbst, 1783) (Flores et al. 2003). Information on more developed larval stages other than the zoea I is scarce and based on specimens collected from plankton samples. Only the zoeae I-V attributed to G. strigosus Herbst, 1799, and the megalopa of G. longitarsis Dana, 1851, have been described by Gohar and AlKholy (1957) and Chen (1995) respectively.

The second zoeal stage of G. adscensionis is described and illustrated in detail, and the morphological features are compared with previous descriptions of this species and congeners, as well as the remaining Grapsidae.

\section{Material and methods}


Three ovigerous females of Grapsus adscensionis were captured by hand at night time from the supralittoral zone of Taliarte Harbor, Gran Canaria, Canary Islands

$\left(27^{\circ} 59.43^{\prime} N, 15^{\circ} 22.04^{\prime} W\right)$ in September 2004. Species identification was based on the morphological descriptions provided by Manning \& Chace (1990).

Individuals were transported to the culture laboratory of the Instituto Canario de Ciencias Marinas (ICCM) close to the sampling site. Females were placed in 1001 flowthrough seawater aquarium, in which plastic boxes were introduced to allow the emersion of the crabs. Once larval hatching occurred, the most active larvae were transferred to a 501 grey cylindrical-conical fibreglass tank for a massive culture with gently aerated seawater at a temperature of $22^{\circ} \mathrm{C}$ and subjected to a natural photoperiod regime. The larvae were fed on a mixed diet of microalgae (Chlorella sp.) and rotifers (Brachionus plicatilis (Müller, 1786)). The tanks were checked daily in order to detect larval moulting and to remove the exuviae and dead larvae before supplying food. Ten randomly selected larvae were sorted daily and preserved in $80 \%$ ethanol for taxonomic purpose.

Dissections were made under a Leica MZ6 stereo-microscope and drawings and measurements were carried out using a Zeiss Axioskop compound microscope equipped with a camera lucida. All six zoea II specimens reared were used in the descriptions and measurements. The coxa of the first and second maxillipeds of all zoea II were dissected so no data on the setation of these appendages was included in the description. Long natatory setae on the first and second maxillipeds were drawn truncated. The following dimensions were measured: rostro-dorsal length ( $\mathrm{rdl})$, as the distance between the tips of the dorsal and rostral spines; carapace length $(\mathrm{cl})$, measured from the base of the rostral spine (between the eyes) to the most posterior margin of the carapace; carapace width (cw), distance between the base of each lateral spines of the carapace. Furcal length (fl) was deduced from an imaginary line across the base of the outer seta in the posterior margin of the telson to the furcal tip; basal telson length (bt), from a line across the anterior margin to the posterior margin of the telson (base of the outer seta). Description and figures are arranged according to the standards proposed by Clark et al. (1998).

\section{Results}


High mortality rates were observed in all of the three larval cultures. More than $80 \%$ of the larvae died at the fourth day of the rearing. Only six larvae from one of the three hatches moulted to the zoea II at sixth day, all of which were sorted for morphological studies. All cultures ended around the ninth day when all larvae died.

The zoea I of G. adscensionis was described by Cuesta et al. (1997) and no differences with the zoea I reared in the present study were observed.

\section{Morphological description}

\section{Zoea II}

Size: $\mathrm{rdl}=1.62 \pm 0.02 \mathrm{~mm} ; \mathrm{cl}=0.64 \pm 0.02 \mathrm{~mm} ; \mathrm{cw}=0.67 \pm 0.03 \mathrm{~mm}$.

Cephalothorax (Fig. 1A): Globose and smooth. Dorsal spine with 3 simple setae and protuberances. Rostral spine longer than antenna and with proximal small protuberances. Lateral spines well developed with protuberances. One pair of posterodorsal setae, and one pair of anterodorsal setae. Ventral margin without setae. Eyes stalked.

Antennule (Fig. 1B): Uniramous. Endopod absent. Exopod with 4 terminal aesthetascs (3 long and 1 shorter), 1 simple seta and 1minute seta.

Antenna (Fig. 1C): Protopod well developed, shorther than rostral spine, with two rows of 8-10 spines increasing in size distally. Endopod absent. Exopod present as a small protuberance with 1 simple seta.

Mandible (Fig. 1D): Palp absent.

Maxillule (Fig. 1E): Coxal endite with 6 (3 plumose, 3 plumodenticulate) setae. Basial endite with 6 (3 plumodenticulate cuspidate, 3 plumodenticulate) setae. Endopod 2-segmented, proximal segment with 1 plumodenticulate seta, distal segment with 1 subterminal, and $2+2$ terminal plumodenticulate setae. Exopodal plumose seta present.

Maxilla (Fig. 1F): Coxa bilobed with 5 (2 plumodenticulate, 3 plumose $)+4(1$ plumodenticulate, 3 plumose) setae. Basis bilobed with 5 ( 2 plumodenticulate, 3 plumose $)+4$ (3 plumodenticulate, 1 plumose) setae. Endopod unsegmented, 
bilobed, with $2+2$ long plumodenticulate setae. Scaphognathite with $3+5$ marginal plumose setae.

First maxilliped (Fig. 1G): Basis with 8 simple setae arranged 2+2+2+2. Endopod 5segmented with 1,2,1,2, sparsely plumose setae, and 5 (1 simple subterminal, 4 terminal plumodenticulate setae) setae. Exopod incompletely segmented with 6 long terminal natatory plumose setae.

Second maxilliped (Fig. H): Basis with 4 sparsely plumose setae arranged $1+1+1+1$. Endopod 3-segmented with 0, 1 plumodenticulate, 5 (1 simple subterminal, 1 plumodenticulate subterminal, 2 long and 1 shorter plumodenticulate terminal) setae. Exopod incompletely segmented with 6 long terminal natatory plumose setae.

Third maxilliped: Absent.

Pereiopods: Absent.

Pleon (Figs 1A, 1I): 5 abdominal somites. Dorsolateral processes (knobs) and posterolateral processes on somites $2-5$. Somite 1 with 1 mid-dorsal seta, somites 2-5 with a pair of setae on posterodorsal margin. Pleopods absent.

Telson (Figs 1A): 3 pairs of stout plumodenticulate setae on posterior margin. 3 minute lateral spines at outer base of each furcal arm; wide central part of furcal arms granulose. bt/fl $>1$.

\section{Discussion}

A set of characters allows defining the typical features of the larval stages of grapsids (see Cuesta et al. 1997, 2006; Cuesta \& Schubart 1999), even if the larval morphologies of most grapsids remain unknown. Cuesta et al. (2011) emended the characterization.

According to Cuesta et al. (2011) in the zoeal stages the lateral spines on the cephalothorax are present in the zoea I as a minute rounded knob-like or small hooked projections, but in the zoea II and subsequent stages the lateral spines are well developed, with small tubercles or spines in some cases. The antenna is represented by a well-developed protopod, with spines in a variable number and degree of development, and the exopod is present as a small bud with a terminal simple seta. The exopod is absent in the case of Metopograpsus. The mouthpart setation patterns of the endopods 
of maxillule, maxilla, first and second maxilliped are $(1,1+4),(2,2),(1,2,1,2,5)$, and $(0,1,5)$, respectively. Exceptions are some species of Metopograpsus, with $(0,1,4)$ setae on the second maxilliped endopod. The setation of the basis of the first and second maxillipeds is $(2,2,2,2)$ and $(1,1,1,1)$, respectively. Some setation patterns exist in later stages, changing to $(2,2,3,3)$ in the basis of the first maxilliped. The pleonal somites $3-5$ have clear posterolateral projections. The pleon presents a characteristic fifth somite with large flattened posterolateral extensions in the case of Metopograpsus. The telson shows 1-3 outer lateral spines, with the exception of Metopograpsus. The basal part of the telson is elongated and always longer than the furcal arms, at least in the first zoeal stage. The number of terminal processes on the telson is $(3+3)$ in species with a zoeal development of 5 zoeae (Metopograpsus). At the last stages the number of terminal setae reaches (4+4) in those developments with 6 zoeae (Pachygrapsus marmoratus), and 6+6 in those with eight zoeal stages (Geograpsus lividus).

Regarding the morphological features of the megalopa stage of Grapsidae, Cuesta et al. (2011) stated that the cephalotorax lacks any characteristic protuberances. The antennal flagellum has 8 segments. The mandibular palp 2 segments, with the proximal segment having no setae, and the distal segment with 7-15 setae. The maxillar scaphognathite has $(3+1)$ lateral setae. The uropod exopod has 2 segments, with the proximal segment with 0-3 setae and the distal segment with 11-23 setae. The dactylus of pereiopods 2-4 bears strong spines.

Metopograpsus thus present several features that clearly separate it of the rest of Grapsidae (type of antenna, pleon morphology, telson spinulation, and some setation patterns). This condition is supported by molecular studies where this genus holds a basal position and is well separated of the rest of grapsids (Schubart 2011). In the same study Grapsus results as paraphyletic in its present composition, with G. adscensionis close to G. grapsus, but as separate valid species.

It is not easy to differentiate the species of Grapsus from the rest of grapsids based on our present knowledge of their larval morphologies. There are nevertheless some minor features that allow separating the zoeae of Grapsus, like the presence of dorsolateral knobs in somite 5 , and 2 or 3 outer lateral spines on the telson furcae.

The zoea II of Grapsus adscensionis shows, as expected, well-developed lateral spines on the cephalothorax. Until now, this character had been previously reported 
only in Geograpsus, Goniopsis De Haan, 1833, Metopograpsus, and Pachygrapsus Randall, 1840, the present data representing the first case for the genus Grapsus. However, the absence of data for Leptograpsodes, Leptograpsus H. Milne Edwards, 1853, and Planes Bowdich, 1825, is still a pitfall for establishing this character as common in the family.

The confirmation of the presence of well-developed lateral spines on the cephalothorax will allow the correct identification of zoea II and subsequent stages of G. adscensionis from plankton samples. A recent study focused on the spatial and temporal variability of decapod larvae in the Canary Islands (Landeira et al. 2010) was not able to report the presence of the zoea II or posterior stages of G. adscensionis in the samples, probably due to a misidentification of the larvae, confusing them with those of species of Pachygrapsus.

The larval development of Grapsus strigosus described by Gohar \& Al-Kholy (1957) from larvae collected in the plankton must be considered a misidentification because the zoeal stages do not show lateral spines. Their description is brief and incomplete, and therefore a more detailed comparison is not possible. Furthermore, a total of 5 zoeal stages were described and the larval developments of Grapsus should consist of 6 or more zoeae.

The lateral knobs or hooked projections of the first zoeal stages of $G$. tenuicrustatus, G. fourmanoiri, Pachygrapsus minutus A. Milne-Edwards, 1873, and $P$. plicatus (H. Milne Edwards, 1837) were not found by Flores et al. (2003). These knobs are very small (see Cuesta \& Rodriguez 2000: plate 1A) and they could be easily overlooked. These species are expected to have well-developed lateral spines starting with the second zoeal stage.

\section{Acknowledgements}

The authors thank to Daniel Montero and Javier Roo for providing culture facilities at the Instituto Canario de Ciencias Marinas, ICCM. We wish to acknowledge Peter Castro (California State Polytechnic University, Pomona) and an anonymous reviewer for valuable comments to the manuscript. 


\section{References}

Chen, W-J. (1995) Studies on the Taxonomy of the Crab Megalopae Collected from Tungkang Coast. Unpublished M.Sc. Thesis, National Sun Yat-Sen University, Kaoshiung, Taiwan, 137 pp. [In Chinese]

Clark, P.F., Calazans, D.K. \& Pohle, G.W. (1998) Accuracy and standardization of brachyuran larval descriptions. Invertebrate Reproduction and Development, 33, $127-144$.

Cuesta, J.A. \& Rodríguez, A. (2000) Zoeal stages of the intertidal crab Pachygrapus marmoratus (Fabricius, 1787) (Brachyura: Grapsidae) reared in the laboratory. Hydrobiologia, 436, 119-130.

Cuesta, J.A. \& Schubart, C.D. (1999) First zoeal stages of Geograpsus lividus and Goniopsis pulchra from Panama confirm consistent larval characters for the subfamily Grapsinae. Ophelia, 51, 163-176.

Cuesta, J.A., González-Gordillo, J.I. \& Rodríguez, A. (1997) First zoeal stages of Grapsus adscensionis (Osbeck) and Planes minutus (Linnaeus) (Brachyura: Grapsidae) described from laboratory hatched material, with notes on larval characters of the Grapsinae. Journal of Natural History, 31, 887-900.

Cuesta, J.A., Guerao, G., Liu, H-C. \& Schubart, C.D. 2006. Morphology of the first zoeal stages of eleven Sesarmidae (Crustacea, Brachyura, Thoracotremata) from the Indo-West Pacific, with a summary of familial larval characters. Invertebrate Reproduction and Development, 49, 151-173.

Cuesta, J.A., Guerao, G., Schubart, C.D. \& Anger, K. (2011) Morphology and growth of the larval stages of Geograpsus lividus (Crustacea, Brachyura), with the descriptions of new larval characters for the Grapsidae and an undescribed setation pattern in extended developments. Acta Zoologica, 92, 225-240.

Flores, A.A.V., Paula, J. \& Dray, T. (2003) First zoeal stages of grapsoid crabs (Crustacea: Brachyura) from the East African coast. Zoological Journal of the Linnean Society, 137, 355-383.

Gohar, H.A.F. \& Al-Kholy, A.A. (1957) The larvae of some brachyuran Crustacea. Publications of the Marine Biological Station, Gardaqa, 9, 145-176. 
Guerao, G., Schubart, C.D. \& Cuesta, J.A. (2001) The first zoeal stages of Grapsus grapsus (Linnaeus) and Geograpsus lividus (H. Milne Edwards) (Decapoda, Brachyura, Grapsidae) from the western Atlantic. Nauplius, 9, 111-121.

Ingle, R.W. (1987) The first zoea of three Pachygrapsus species and of Cataleptodius floridanus (Gibbes) from Bermuda and Mediterranean (Crustacea: Decapoda: Brachyura). Bulletin of the British Museum (Natural History), Zoology, 52, 31-41. Landeira, J.M. (2010) Larvas planctónicas de crustáceos decápodos en las Islas Canarias. Unpublished Ph. D. Thesis. Servicio de Publicaciones de la Universidad de La Laguna. Serie Tesis Doctorales, Ciencias y Tecnologías, 32, 138 pp. [In Spanish]

Manning, R.B. \& Chace, Jr., F.A. (1990) Decapod and stomatopod Crustacea from Ascension Island, South Atlantic Ocean. Smithsonian Contributions to Zoology, 503, 1-91.

Schubart, C.D. (2011) Reconstruction of phylogenetic relationships within Grapsidae (Crustacea: Brachyura) and comparison of trans-isthmian versus amphi-atlantic gene flow based on mtDNA. Zoologischer Anzeiger, 250, 472-478.

\section{[Figure caption]}

FIGURE 1. Grapsus adscensionis, zoea II. a, lateral view, whole larva, with detail of lateral spine; b, antennules; c, antenna; d, mandible; e, maxillule; f, maxilla; g, first maxilliped; h, second maxilliped; i, pleon, dorsal view, with detail of furca. Scale bars: $\mathrm{a}=100 \mu \mathrm{m} ; \mathrm{b}-\mathrm{h}=50 \mu \mathrm{m} ; \mathrm{i}=200 \mu \mathrm{m}$. 